\title{
Being there: strategies for incorporating the student voice into the learning experience of a large first-year marketing course in a New Zealand university
}

\author{
Mary FitzPatrick, University of Waikato, New Zealand \\ Janet Davey, University of Waikato, New Zealand \\ Dorothy Spiller, University of Waikato, New Zealand
}

\begin{abstract}
Higher education (HE) researchers and practitioners comment regularly on the difficulties of encouraging students to be fully present in the large-class learning experience. Educators who want to honour and promote the student voice need to design teaching and learning spaces that help students make emotional and cognitive connections with course learning, enabling them to be partners in directing the learning and to assume the role of co-inquirers. This paper describes a case study in a first-year marketing course in a New Zealand university in which a student tutor's photo-narrative was designed to achieve these goals. Students' evaluations indicated that the strategy promoted personal engagement and increased ownership of the learning. Photonarrative storytelling offers HE practitioners an effective means to connect theoretical content to students' own lives, and enhance student ownership of the learning. Inviting students to create their own photo-narratives could create a learning experience that approximates more closely to a learning partnership.
\end{abstract}

Keywords: Student ownership; tutors; storytelling.

\section{Introduction}

For novice students, the large first-year classroom and the culture of an academic space may feel alien and uninviting, as well as remote from everyday experience. However, as theorists such as Illeris (2009) remind us, change in thinking or behaviour, which is the hallmark of genuine learning, requires a combination of affective and cognitive elements to occur. We argue that such learning is effectively supported by setting up learning environments to enable students to articulate their voices and assume the role of partners and co-inquirers in the learning process (e.g. Baxter Magolda, 1996). Such learning partnerships are imperative if students are going to be able to engage independently, critically, and effectively in contemporary society and in the workplace. Academic practitioners in large first-year classes are consequently faced with the challenge of creating learning opportunities that are both emotionally and cognitively close to the students' experience and that encourage students to shape the direction of the class. It is suggested that handing over responsibility for directing the learning to students is an integral part of bringing their voices into the learning space.

This paper outlines and discusses a teaching and learning initiative designed and implemented in a large first-year marketing course in a New Zealand (NZ) university. This introductory marketing course is a core course for all students enrolled in a four-year business management 
degree, with approximately 600 students taking the course every year. The study examines the extent to which the teaching and learning initiative helped to enhance students' affective and cognitive engagement with course learning - moving students from the position of passive recipients to co-inquirers. Two key strategies were combined to increase students' connection to the learning and to enhance their voice in the learning space. These strategies were the use of a student tutor and the technique of storytelling. The exercise brings together the fields of scholarship relating to tutor roles and to storytelling in marketing education. Student tutors are pivotal to this instructional exercise, which extends their traditional teaching role from tutoring small groups of students 'behind the scenes', to mediating teaching and learning in the largeclass lecture theatre. In the context of NZ universities, it should be noted that the term 'tutor' is used to describe postgraduate or undergraduate students who are appointed on casual contracts, usually to facilitate small class learning and to mark students' work. Storytelling in this instance was used in relation to the learning of a foundational marketing framework; namely the consumer decision-making process.

First-year students frequently have problems differentiating the frameworks used to model some of the key processes that are fundamental to marketing theory and practice. The consumer behaviour topic, for instance, is built on several of these foundational processes. While models of these processes certainly simplify the complexity of consumer behaviour for first-year students, generalised models dehumanise patterns of behaviour and concept-heavy textbooks typically pay little attention to the connections between theoretical frameworks and students' everyday life as consumers (Levin \& Martin, 2010; Myers 2010). The first-year marketing students have had years of experience as consumers; thus, a textbook-based teaching approach that ignores students' prior experience can exacerbate student disconnection from the discipline. The firstyear lecturer needs to find ways of connecting what Palmer calls 'the big stories' of the discipline with the 'little stories' of the individuals in the class (1998, p.74).

\section{Teaching and learning strategies and underpinning scholarship}

\section{Using student tutors in large first-year classes}

The challenges of teaching students in large classes have been well-documented. They include the potential passivity, apathy, and anonymity of the students, and the difficulties of conducting dialogue that plague both lecturer and students (FitzPatrick et al., 2010). The physical layout of many large lecture theatres positions the lecturer as an authoritative expert at the front of the room and sets up an immediate distance between teacher and learners. This power distance is compounded by other critical gaps between lecturers and students, particularly first-year students. Some of these differences are due simply to maturity and life experience; others relate to first-year students' prior learning experiences, their expectations of university, and their motivation to learn and/or succeed. These disconnections can intensify the sense of alienation for students: 
'When someone with the authority of a teacher...describes the world and you are not in it, there is a moment of psychic disequilibrium, as if you looked into a mirror and saw nothing' (Kajder, 2004, p.64).

Moreover, large first-year classes generally include a very diverse group of students (Biggs, 1999; McLaren, 2001). As well as demographic, cultural, and educational diversity, first-year students are likely to have little common ground in relation to the specific subject content to which they are being introduced, because it involves both a new academic discipline and unfamiliar theoretical concepts. Such complex diversity can be difficult to cater for in a classroom environment in which the voice of the lecturer is generally the dominant, if not the only, voice.

Engaging students can be especially challenging in the context of a large first-year class, when a significant number of students feel unconfident, depersonalized, and isolated from their teachers and fellow students, as well as disconnected from the subject itself (e.g. Krause \& Coates, 2008). Engagement, which is a meta-construct in the pedagogy of teaching and learning, is increasingly understood to be an indicator of 'successful' learning and the outcome of 'effective' teaching (Knight, 2002). As a multi-faceted construct, engagement comprises aspects of substantive realworld relevance, effective learning of the topic, attention-getting, personalisation, and relateability (as represented by the five statements of student engagement in our assessment - see Table 1).

Some educationalists hold that it is helpful to 'mediate' student learning in order to improve engagement, and that learners engage within networks of others as well as with the material (e.g. Volkert, 2012). Student tutors, frequently a part of the first-year experience, can play a significant role in mediating student learning (e.g. Chng et al., 2011). Scholars acknowledge these older and more knowledgeable students in terms of their relationship value, drawing on participatory and relational pedagogies to highlight the importance of the "intersubjective recognition" (Murphy \& Brown, 2012, p.6) that occurs within the tutor-student relationship. Because student tutors are typically closer to the students in age than the lecturer, often still studying themselves, and sharing a similar lifestyle and worldview, they can be valuable in redressing some of the power issues experienced in the large-class lecture environment (Muzaka, 2009; Murphy \& Brown, 2012). When some of these power issues are addressed, students may feel a greater emotional ease in the classroom that feeds into their capacity to engage cognitively with course concepts. Such factors explain the positive impact student tutors can have on student engagement and retention (e.g. Muzaka, 2009; Chng et al., 2011). Finally, research confirms that student tutors can be critical partners in student-centred learning exercises (Wright et al., 2011).

\section{Storytelling in Teaching and Learning}

Storytelling has been acknowledged as a particularly effective means of communicating marketing and management concepts (Short \& Reeves, 2009; Das, 2012). Storytelling enables students to connect theoretical learning to their own lives, build connections across the learning community, and find points of commonality that can help to draw the individual into a collective learning experience. The use of stories that relate to students' lives provides a natural way of 
bringing students' voices into the learning experience and enabling students to shape the direction of the learning. In particular, honouring the "little stories of the individual" (Palmer 1998 , p.74) in the classroom provides a natural way of bringing together the public world of the academic discipline with the private day-to-day lives of students:

'Students are more likely to take ownership of the meanings and structures presented within a new domain of knowledge if they can link it to the familiar' (Miley, 2009, p.358)

Stories, the primary tool that people use in the process of making meaning, are especially valuable in teaching and learning contexts (Rossiter, 2002; Moon, 2010). Stories have the power to reach us both through the cognitive framework they provide (Hopkins, 1994), as well as through their capacity to connect individuals through archetypal narratives about the human condition. In the context of our large first-year marketing class, stories offer students a way of stitching together the mini-narratives of their own experience and the sense-making 'storying' offered by the theoretical perspective of the discipline. Furthermore, if the story is one that belongs to the world of the students, it can provide a point of common entry into the academic discipline.

In academic settings, the 'photo-narrative', a story told with photos and dialogue, is emerging as a powerful educational tool that can be both informative and engaging. The use of visual images to optimise engagement and learning effectiveness is strongly supported in the literature (Robin, 2008a, 2008b; Strauss et al., 2011; Steffes \& Duverger, 2012). When visual images coincide with narratives in teaching, students can build two mental representations - strengthening their cognitive processing and assisting in learning (Ng, 2006; Strauss et al., 2011). Photo-narratives deliberately constructed to enhance learning have been shown to reinforce students' comprehension, increase depth and speed of understanding, aid cognitive efficiency, enhance recall, and improve connections both to the topic itself and between concepts and their application (Ng, 2006; Das, 2012; Steffes \& Duverger, 2012).

\section{The Teaching Exercise}

The overarching pedagogical goal of the teaching exercise described in this paper is to enhance engagement by building connections between theory and the real-world. To facilitate these connections we chose to design the teaching exercise drawing on storytelling approaches, based on the literature that supports the use of visuals to optimise engagement and learning effectiveness. Student tutors are central to this teaching exercise, which effectively extends their traditional teaching role from tutoring small groups of students to mediating teaching and learning in the large class lecture theatre.

The teaching exercise is used in an introductory marketing course that is a core course for all students enrolled in a four-year management degree. Approximately 300 students take the course in each of the two semesters it is run every year, typically aged between 17 and 21 years and with slightly more female students than males. While all the students have met NZ standard university entry requirements, the NZ students come from a range of educational and socioeconomic backgrounds. In addition, the first-year student cohort is ethnically diverse; more than

\begin{tabular}{r|r} 
M. FitzPatrick & 41 \\
J. Davey & \\
D. Spiller &
\end{tabular}


2,000 international students (about $17 \%$ of the total student numbers) from over 70 countries study at the university that is the site of this research.

The exercise is built on the consumer decision-making behaviour of Kahu, an undergraduate student tutor completing a conjoint degree in marketing and law. His photo-narrative recorded his decision-making process and final purchase of a new tablet computer, starting with close-up photos of his old computer. Early on in his information gathering, Kahu searched online and gathered detailed specifications of the various tablet alternatives. He also asked for advice from his father and a close friend, and for hands-on trial experience Kahu visited a large well-known retailer of electrical goods.

Kahu came into the large lecture theatre and narrated his photo-narrative, telling his story in the form of an interactive conversation with the students. As his story unfolded, the lecturer and students asked questions to elicit more details, effectively deepening their engagement with the learning experience. In order to reinforce the connections between Kahu's real-life example and the theoretical model, the lecturer repeated the main theoretical points of the five-step consumer decision-making process on a document camera, coinciding with Kahu's photo-narrative. Previous research has found such 'multi-task' presentations providing simultaneous visual material congruent with text material enhance retention and recall for millennials (Steffes \& Duverger, 2012).

\section{Results}

At the conclusion of the consumer behaviour topic during which the storytelling exercise was implemented, all students were invited to participate in a short anonymous survey; 171 of the $300(57 \%)$ enrolled students completed the survey. The gender and age distributions of the respondents were representative of the whole class cohort. The students were asked to assess the teaching exercise according to six statements using a 5-point scale (refer Table 1) on items of: real-world relevance, effective learning of the topic, attention-getting, personalisation and interest-sustaining, and relate-ability. The survey concluded with an open-ended question asking the students to comment on how the exercise helped them learn about consumer behaviour. Participation in the survey was not compulsory and did not contribute to their course grade. It is important to note that students who participated in the survey may have been those who were more engaged in their studies irrespective of teaching mode.

The student responses (see Table 1) indicated that they valued all the aspects purposefully built into the teaching exercise. Although the data supported the photo-narrative as being relevant, attention-getting, and interesting to students, the two statements 'connected theory to real-life' and 'helping students to learn about the consumer decision-making process' were rated much higher than the other aspects. The students strongly agreed that the photo-narrative exercise, which enabled them to make connections, was both informative and engaging:

'[Kahu's example was] easy to understand because we listened to his story and looked at the pictures - visual and verbal - it was cool'. 
Relating to the specific aspects of engagement, the mean ratings for the three aspects of attention-getting (4.15), relevance (4.10), and interest-sustaining (4.05) reflect the students' acknowledgment that all three aspects contribute to their engagement with the photo-narrative exercise. The qualitative data explained the connections students were able to make between theory and real-life, between the big stories of the discipline and the students' personal stories. For example:

'...it put the [marketing course] content into context which gave me a deeper understanding'.

'As I was watching Kahu's example, I was retracing my own steps relating to my purchase...this helped it 'stick' in my brain'.

'I liked that the example applied the course theory to real life as it helps to understand the theory'.

Students also agreed that the student tutor participation was a valuable aspect of the photonarrative exercise:

'I don't need to refer to notes ever again. Just think of Kahu and Consumer Decision-Making just pops up (-)'.

\begin{tabular}{|lccl|}
\hline \multicolumn{1}{|c}{ Item $^{*}$} & Mean & SD & \multicolumn{1}{c|}{ Adapted from } \\
\hline $\begin{array}{l}\text { The example connected theory to } \\
\text { real life }\end{array}$ & 4.46 & .627 & $\begin{array}{l}\text { Karns, 2006; Matulich } \text { et } \\
\text { al., 2008. }\end{array}$ \\
\hline $\begin{array}{l}\text { The example helped me to learn } \\
\text { about the consumer decision- } \\
\text { making process }\end{array}$ & 4.26 & .709 & $\begin{array}{l}\text { Sampson \& Betters-Reed, } \\
\text { 2008; Young et al., } 2003 .\end{array}$ \\
\hline The example grabbed my attention & 4.15 & .721 & Strauss et al., 2011. \\
\hline $\begin{array}{l}\text { The example was relevant to me as } \\
\text { a student }\end{array}$ & 4.10 & .870 & Taylor et al., 2011. \\
\hline The example held my interest & 4.05 & .747 & Short \& Reeves, 2009. \\
\hline $\begin{array}{l}\text { The example was easy to relate to } \\
\text { because it involved one of our } \\
\text { tutors }\end{array}$ & 3.76 & .923 & $\begin{array}{l}\text { Levin \& Martin, 2010; } \\
\text { Paswan \& Young, 2002. }\end{array}$ \\
\hline
\end{tabular}

Table 1. Students' assessment of the teaching exercise

* Survey items are listed in descending order by response mean as measured on a five-point scale, $5=$ strongly agree, $3=$ indifferent or neutral, $1=$ strongly disagree. 


\section{Conclusion}

Students' comments reflected a personal engagement with the material that had both emotional and cognitive dimensions. The easy familiarity of the phrase 'just think of Kahu' suggests that the use of the student tutor has enabled course learning to shift out of an abstract domain and into the students' world. Similarly, the phrase 'just pops up' suggests a comfortable integration into the students' own way of thinking and engaging. In addition, the effectiveness of the combination of student tutor and storytelling mode in enhancing student ownership of the learning is demonstrated in the phrase 'I was retracing my own steps'.

In the first-year marketing classroom, the photo-narrative as a specific form of storytelling allows first-year students to literally 'see' in Kahu's story the real-world connections between theory and practice, between discipline-specific knowledge and real-world knowledge. Or, using Parker's metaphor (1998), the student tutor's 'little story' facilitates student engagement of marketing's 'big stories'. These connections, which link their existing knowledge to new knowledge and make unfamiliar content more understandable, enhance students' ability to think and practise according to the marketing discipline, which is particularly relevant when graduate employment is challenging (Wright \& Gilmore, 2012).

Student data confirmed that the photo-narrative exercise enhanced connections between theory and real-life, and results also indicate that these connections deepened their learning. Qualitative results supported the effectiveness of congruent imagery and text in engaging students with unfamiliar, complex theoretical content. Students' comments also confirmed improved encoding and retention of content, in line with previous research.

In terms of students becoming co-inquirers it is argued that improvements could be made to this initiative. While the student tutor provides a bridge between the academic content and students' voices, the exercise does not enable students to craft their own stories and become even more active partners in the learning process. Future iterations could extend the exercise by having students create and present their own photo-narratives. Not only could such an initiative enhance the learning by underpinning it with multiple narratives, but students would be compelled to narrate the process and its implications in their own voice. Such an activity would open up points of inquiry which are outside the control of the teacher and the tutor and so create a more authentic platform for learning partnership and co-inquiry. Finally, the exercise could become more interactive by incorporating social media (e.g. Facebook) into the students' photonarratives to draw on the benefits of student-to-student peer learning. Future research could assess the teaching effectiveness of these developments along with more detailed investigation of specific influences (e.g. gender) on student engagement with photo-narratives and the importance of student tutor interaction as part of the student experience.

This research is limited by several conditions. It was a small-scale descriptive student survey administered in a single iteration of a single course with no comparative evaluation of other modes of delivery. Additionally, we relied on students' self-reports of their engagement and learning experiences. Nonetheless, there is encouraging evidence in the results of the engagement benefits to higher education students: student data show that the teaching exercise 
delivered on all aspects of engagement suggesting that the photo-narrative form of storytelling provides a valuable opportunity to construct a meaningful learning interaction.

\section{References}

Baxter Magolda, M. (1996) 'Epistemological development in graduate and professional education'. Review of Higher Education. 19 (3): 283-304.

Biggs, J. (1999) 'What the student does: Teaching for enhanced learning'. Higher Education Research \& Development. 18 (1): 57-75. http://dx.doi.org/10.1080/0729436990180105

Chng, E., Yew, E. H. J. and Schmidt, H. G. (2011) 'Effects of tutor-related behaviours on the process of problem-based learning'. Advances in Health Science Education. 16 (4): 491-503. http://dx.doi.org/10.1007/s10459-011-9282-7

Das, K. (2012) 'Using participatory photo novels to teach marketing'. Journal of Marketing Education. 34 (1): 82-95. http://dx.doi.org/10.1177/0273475311430812

FitzPatrick, M., Davey, J. and van Oostrom, M. (2010) 'Getting personal with marketing research: A first year teaching innovation'. International Journal of the First Year in Higher Education. 1 (1): 84-90.

Hopkins, R. L. (1994) Narrative schooling: Experiential learning and the transformation of American education. New York: Teachers College Press.

Illeris, K. (2009) A comprehensive understanding of human learning. In Illeris, K. (ed) Contemporary theories of learning: Learning theorists...in their work words. Milton Park, UK: Routledge, 7-21.

Kajder, S. (2004) 'Enter here: Personal narrative and digital storytelling'. English Journal. 93 (3): 64-68. http://dx.doi.org/10.2307/4128811

Karns, G. L. (2006) 'Learning style differences in the perceived effectiveness of learning activities'. Journal of Marketing Education. 28 (1): 56-63. http://dx.doi.org/10.1177/0273475305284641

Knight, P. T. (2002) 'Summative assessment in higher education: practices in disarray'. Studies in Higher Education. 27 (3): 275-286. http://dx.doi.org/10.1080/03075070220000662

Krause, K-L. D. and Coates, H. (2008) 'Students' engagement in first year university'. Assessment and Evaluation in Higher Education. 33 (5): 493-505. http://dx.doi.org/10.1080/02602930701698892

Levin, A. M. and Martin, G. S. (2010) 'High-involvement learning: The student insight panel'. Marketing Education Review. 20 (2): 173-177. http://dx.doi.org/10.2753/MER1052-8008200208 
Matulich, E., Papp, R. and Haytko, D. L. (2008) 'Continuous improvement through teaching innovations: A requirement for today's learners'. Marketing Education Review. 18 (1): 1-7.

McLaren, A. (2001) The admissions system: Expansion, inclusion and the demands of diversity. In Warner, D. and Palfreyman, D. (eds) The state of UK higher education: Managing change and diversity. Philadelphia: Open University Press, 116-125.

Miley, F. (2009) 'The storytelling project: innovating to engage students in their learning'. Higher Education Research and Development. 28 (4): 357-369.

http://dx.doi.org/10.1080/07294360903046892

Moon, J. (2010) Using Story in higher education and professional development. Milton Park, UK: Routledge.

Murphy, M. and Brown, T. (2012) 'Learning as relational: Intersubjectivity and pedagogy in higher education'. International Journal of Lifelong Education. 31 (5), 643-654.

http://dx.doi.org/10.1080/02601370.2012.700648

Muzaka, V. (2009) 'The niche of graduate teaching assistant (GTAs): Perceptions and reflections'. Teaching in Higher Education. 14 (1): 1-12.

http://dx.doi.org/10.1080/13562510802602400

Myers, S. D. (2010) 'Experiential learning and consumer behavior: An exercise in consumer decision making'. Journal for Advancement of Marketing Education. 17: 23-27.

Ng, I. C. (2006) 'Photoessays in the teaching of marketing'. Journal of Marketing Education. 28 (3): 237-253. http://dx.doi.org/10.1177/0273475306291468

Palmer, P. J. (1998) The courage to teach: Exploring the inner landscape of a teachers' life. San Francisco: Jossey-Bass.

Paswan, A. K. and Young, J. A. (2002) 'Student evaluation of instructor: A nomological investigation using structural equation modelling'. Journal of Marketing Education. 24 (3): 193202. http://dx.doi.org/10.1177/0273475302238042

Robin, B. R. (2008a) 'Digital storytelling: A powerful technology tool for the 21 st century classroom'. Theory into Practice. 47 (3): 220-228.

http://dx.doi.org/10.1080/00405840802153916

Robin, B. R. (2008b) The effective uses of digital storytelling as a teaching and learning tool. In Flood, J., Heath, S. B. and Lapp, D. (eds) Handbook of research on teaching literacy through the communicative and visual arts Vol. II. New York: Lawrence Erlbaum Associates, 429-441. 
Rossiter, M. (2002) 'Narrative and stories in adult teaching and learning'. ERIC Digest, 241. Retrieved from http://calpro-online.org/eric/docs/dig241.pdf

Sampson, S. D. and Betters-Reed, B. L. (2008) 'Assurance of learning and outcomes assessment: A case study of assessment of a marketing curriculum'. Marketing Education Review. 18 (3): 2536.

Short, J. C. and Reeves, T. C. (2009) 'The graphic novel: A "cool” format for communicating to Generation Y'. Business Communication Quarterly. 72 (4): 414-430. http://dx.doi.org/10.1177/1080569909336464

Steffes, E. M. and Duverger, P. (2012) 'Edutainment with videos and its positive effect on long term memory'. Journal for Advancement of Marketing Education. 20 (1): 1-10.

Strauss, J., Corrigan, H. and Hofacker, C. F. (2011) 'Optimizing student learning: Examining the use of presentation slides'. Marketing Education Review. 21 (2): 151-162. http://dx.doi.org/10.2753/MER1052-8008210205

Taylor, S. A., Hunter, G. L., Melton, H. and Goodwin, S. A. (2011) 'Student engagement and marketing classes'. Journal of Marketing Education. 33 (1): 73-92.

Volkert, A. (2012) 'An action research project to explore the effect of an established preassessment intervention with undergraduate occupational therapy students'. Enhancing the Learner Experience in Higher Education. 4 (1): 32-43.

Wright, A. L. and Gilmore, A. (2012) 'Threshold concepts and conceptions: Student learning in introductory management courses'. Journal of Management Education. 36 (5): 614-635. http://dx.doi.org/10.1177/1052562911429446

Wright, M. C., Bergom, I. and Brooks, M. (2011) 'The role of teaching assistants in studentcentered learning: Benefits, costs, and negotiations'. Innovative Higher Education. 36 (5): 331342. http://dx.doi.org/10.1007/s10755-011-9197-5

Young, M. R, Klemz, B. R. and Murphy, J. W. (2003) 'Enhancing learning outcomes: The effects of instructional technology, learning styles, instructional methods, and student behaviour'. Journal of Marketing Education. 25 (2): 130-142.

http://dx.doi.org/10.1177/0273475303254004

\section{About the authors}

Dr. Mary FitzPatrick, is a Senior Lecturer in the Department of Marketing, Waikato Management School.

Principal author email: maryfitz@waikato.ac.nz 
Janet Davey is a $\mathrm{PhD}$ candidate at the University of Waikato, and Dorothy Spiller is a teaching and learning facilitator at the University of Waikato. 